\title{
Chapter 25 \\ Article 33: The Right to Protection from \\ Illicit Use of Narcotic Drugs \\ and Psychotropic Substances
}

\section{Damon Barrett and Ziba Vaghri}

States Parties shall take all appropriate measures, including legislative, administrative, social and educational measures, to protect children from the illicit use of narcotic drugs and psychotropic substances as defined in the relevant international treaties, and to prevent the use of children in the illicit production and trafficking of such substances

\section{What Did Children Say?}

Schools have courses for students and communities to understand well the consequences of harmful drug and know how to deal with the activities of drug trading. (Asia-Pacific)

Governments should follow international treaties to determine which substances should be legal or illegal. (Eastern Europe)

Governments should allow substances to be supplied in a safe way. (Eastern Europe)

Control over pharmaceutical companies. (Eastern Europe)

D. Barrett

University of Gothenburg, Göteborg, Sweden

e-mail: damon.barrett@gu.se

Z. Vaghri $(\bowtie)$

University of New Brunswick, Saint John, Canada

e-mail: ziba.vaghri@unb.ca 


\section{Overview}

Article 33 enshrines the right to protection from narcotic drugs and psychotropic substances. It has no equivalent in earlier human rights treaties (Barrett, 2020, pp. 19-59). The later ILO Convention 182, in Article 3(c), and the African Charter on the Rights and Welfare of the Child, in Article 28, complement the provision. While originally discussed as part of the draft provision on the right to health, the Article was ultimately placed between provisions on economic and sexual exploitation, though there was little discussion in drafting as to what the provision required (Barrett, 2020, pp. 50-59; Office of the United Nations High Commissioner for Human Rights and Rädda barnen (Society: Sweden), 2007).

There are two related but separate clauses in Article 33: the protection of children from illicit use, and the prevention of the use of children in illicit production and trafficking. Thus, the former is placed by the Committee (since 2010) within basic health and welfare cluster, while the latter is assessed as a special protection measure (UN Committee on the Rights of the Child, 2010). The phrase 'shall take' indicates a strong formulation that, commensurate with other provisions in the Convention, requires positive obligations on the part of States Parties.

While protecting children from drugs is self-evidently important, the means to do so are a constant political and social debate. Article 33 is very generally framed and finds itself within a contested area of law and policy. Protecting children from drugs and the drug trade could cover all drug policy. The added value of the Convention provision is in bringing the question of drug use and the drug trade into the normative child rights framework. ${ }^{1}$ Thus, rather than merely providing a child rights rationale for existing drug laws and policies, the periodic reporting process is an opportunity for critical child rights reflection on them. What, in other words, are the appropriate legislative, administrative, social, and educational measures for the achievement of the aims of Article 33? This approach requires unpacking the normative content of appropriate measures.

It is also important to note that this provision clearly links Article 33 to the UN drug control conventions listed in the Relevant Instruments section. The drafting history demonstrates, however, that the reference to the 'relevant international treaties' was intended to demarcate the substances in question rather than to indicate which measures are appropriate to take (Barrett, 2017). There are good reasons for this, including that there are parties to the Convention on the Rights of the Child that are not parties to drug control conventions (Barrett, 2019).

However, as the scope of Article 33 is defined by reference to substances 'defined in the relevant international treaties,' when the UN Commission on Narcotic Drugs places a new substance under international control, that decision engages the obligations of all parties to the Convention on the Rights of the Child (Barrett and Lohman, 2020). Alcohol and tobacco are, strictly speaking, omitted as they are not

\footnotetext{
${ }^{1}$ For a discussion, see 'Article 33: Protection from Narcotic Drugs and Psychotropic Substances' (Barrett and Tobin, 2019).
} 
captured by these treaties, though these have been addressed by the Committee under the broader umbrella of 'adolescent health' (Barrett, 2020, pp. 132-135).

The provision does not relate to licit uses of controlled substances. These include opiates for the control of pain, such as morphine. Instead, children have the right to access such essential medicines under Article 24 (discussed earlier in this part). However, controlled medicines are lacking for about two-thirds of the world's population, according to the WHO. It is an area the Committee has yet to address in the light of this connection between Articles 24 and 33.

Similarly, Article 33 does not cover licit production, such as licenced opium poppy production. Instead, any such work is covered by Article 32. The difference is that Article 32 entails a qualitative assessment of working conditions based on child labour standards, whereas Article 33 is an absolute prohibition as a worst form of child labour (see also, ILO Convention 182) (Barrett and Lohman, 2020).

\section{General Principles}

Article 2 Understood in a negative sense, there are various ways in which children and young people may be discriminated against in drug policy, for example, through legal age restrictions on access to services without a medical or ethical basis. In a more positive sense, States Parties have obligations to ensure the collection of adequately disaggregated data on drug use to uncover patterns of vulnerability and target those in need. However, drug use data are poor outside of high-income countries, where there are significant difficulties collecting such information.

Article 3 In general, the best interests principle leads to a similar dilemma as that posed by Article 33 itself. It is not agreed which legal and policy approaches are in children's best interests. It is likely more fruitful to apply the test to specific context than to attempt to link it to broad policy prescriptions, e.g., replacing the kinds of legal age restrictions noted above with best interests assessments.

Article 6 Problematic drug use is a mix of personal and environmental factors. Article 6 speaks to the necessity of viewing the drugs issue holistically, rather than to focus on enforcement, where most drug policy budgets are directed. Contemporary epidemiological and prevention evidence suggests a need to focus on social and economic determinants, and on resilience and empowerment instead of 'just say no' messaging.

Article 12 In practice, children are rarely consulted in the development of drug policies. Article 12 would require that their views and experiences are gathered and applied to inform legislation and policy governing drug use, including issues such as random school drug testing and compulsory drug treatment. 


\section{Articles Related or Linked to Article 33}

Given the widespread influence of the drug issue on many spheres of children's lives, there are few Convention articles to which Article 33 is not connected. Specifically, however:

- Article 13, children have the right to receive 'accurate and objective' information about drugs and related harms (Barrett and Tobin, 2019).

- Article 17, children should be protected from misinformation about drugs and from material injurious to their well-being. ${ }^{2}$

- Article 18(2), children of parents with drug dependence are at risk of later drug use themselves. Assistance to such parents is an important form of protection.

- Article 19, children who use drugs, with parents who are drug dependent, and those involved in the drug trade are at risk of various forms of neglect and abuse.

- Article 24, children and young people who use drugs do not forfeit their right to health, and require programmes targeted for their health needs (UN Committee on the Rights of the Child, 2003, 2013, Article 24, 2016).

- Article 27, children involved in the drug trade are often from poor socioeconomic backgrounds.

- Article 28, as education plays a protective role with regard to delaying drug use initiation and protecting children from exploitation. However, some school-based interventions may violate the right to education, including random testing, sniffer dogs, and strip searches.

- Article 30, as the rights of indigenous children or children from minority groups to enjoy their culture may clash with Article 33. For example, chewing coca leaf is an indigenous practice in the Andean region, but banned under the UN drugs conventions ('the relevant international treaties' for Article 33).

- Article 31, as many young people initiate drug use out of boredom and a lack of other activities.

- Article 37, as children and young people who use drugs and that have been involved in the drug trade have been subjected to cruel, inhuman, and degrading treatment, both at the hands of police and in drug treatment facilities.

- Article 40, since children and young people who use drugs and who are involved in the drugs trade are involved in criminality, therefore requiring attention to juvenile justice standards.

\section{Relevant Instruments}

UN Single Convention on Narcotic Drugs (1961)

\footnotetext{
${ }^{2}$ This arose in Handyside v UK, App No 5493/72, [1976] ECHR 5.
} 
International Covenant on Economic, Social and Cultural Rights (1966), Articles 10(3) and 12

International Covenant on Civil and Political Rights (1966), Article 24(1)

UN Convention on Psychotropic Substances (1971)

UN Convention against Illicit Traffic in Narcotic Drugs and Psychotropic Substances (1988)

WHO Framework Convention on Tobacco Control (2005)

ILO Convention 182, Worst forms of child labour (1999)

African Charter on the Rights and Welfare of the Child (1990), Article 28

\section{Attributes}

\section{Attribute One: Protection from the Illicit Use of Narcotic Drugs and Psychotropic Substances}

The Committee has issued hundreds of concluding observations raising drugs issues. Several General Comments are also relevant. Clearly, States Parties have prevention and treatment obligations relating to drug use, and this has been the overwhelming focus of the Committee's recommendations (Barrett, 2020, pp. 125-137). ${ }^{3}$ More recently, the Committee has recommended harm reduction measures for children and young people who use drugs. It has recommended accurate and objective drugs information, schools-based programmes, healthy lifestyles and life skills education, access to services without parental consent, and youth-friendly services. Children who use drugs, moreover, should be treated as victims and not criminals according to the Committee, though the victim label may also be problematised from a child rights perspective. The Committee has also recommended the development of national actions plans and legislative frameworks (Barrett, 2020, pp. 125-137).

Complications arise, however, when questions are asked of what such laws, policies, and interventions entail. It is an area of law and policy that is rife with human rights problems. Random school drug testing as a form of prevention, for example, raises important child rights concerns in terms of consent and the consequences of positives tests for the right to education. Some prevention interventions are not only ineffective but counterproductive. Children have experienced serious abuses in drug treatment centres, which the Committee has strongly condemned (Barrett, 2020, pp. 168-171).

\footnotetext{
${ }^{3}$ See also, UN Commission on Narcotic Drugs, Resolution 58/2 'Supporting the availability, accessibility and diversity of scientific evidence-based treatment and care for children and young people with substance use disorders', 2015; Resolution 60/7 Promoting scientific evidence-based community, family and school programmes and strategies for the purpose of preventing drug use among children and adolescents', 2017.
} 
Accordingly, with regard to protection from illicit use of drugs, States Parties should:

- ensure that state actors do not encourage, expose or facilitate the illicit use of controlled substances by children and do not block or impede prevention, harm reduction and treatment interventions for children who have used such substances (the obligation to respect)

- ensure that non-state actors do not encourage, expose, or facilitate the illicit use of controlled substances by children and do not block or impede effective prevention, harm reduction and treatment interventions (the obligation to protect); create an effective enabling environment for the prevention of drug use by children and the reduction of any health and social harms associated with drug use (the obligation to fulfil) (Barrett and Tobin, 2019)

\section{Attribute Two: Prevention of the Use of Children in Illicit Production and Trafficking}

The balance of concluding observations has been overwhelmingly towards the first clause of Article 33, with very few considering involvement in the drug trade (Barrett, 2020, pp. 125-137). Standards from juvenile justice and economic exploitation (see Part 9), and other areas may, however, be applied. As with protection from illicit use, it may be helpful to again begin with basic standards in order to:

- ensure that state actors do not encourage, expose, or facilitate the use of children in the illicit production and trafficking of the substances controlled by the relevant international instruments (the obligation to respect)

- ensure that non-state actors do not encourage, expose, or facilitate the use of children in the illicit production and trafficking of the substances controlled by the relevant international instruments (the obligation to protect)

- ensure that the underlying reasons for children's involvement in the illicit drug trade are addressed and that those children involved in the drug trade are removed and provided with appropriate measures to address any harm they may have suffered (the obligation to fulfil) (Barrett and Tobin, 2019)

\section{Attribute Three: Appropriate Measures-Rights Compliance and Effectiveness as a Normative Test}

The added value of Article 33 and the periodic reporting process should be as a critical review of what States Parties are doing, based on child rights standards. No other international mechanism has a direct mandate to do this. By and large, however, the periodic reporting process demonstrates that this has not been the 
focus. General Comments and Concluding Observations, and imbalances in focus, tend to reaffirm state actions, whatever these might be, while failing to challenge legal and policy structures for either compliance with child rights or their progress towards the goals enshrined in Article 33 (Barrett, 2020, pp. 148-149).

For a more evaluative lens, Barrett and Tobin have developed a test of appropriate measures based on two complementary top line principles. As with other areas of the Convention, 'appropriate measures' for the purposes of Article 33 must be human rights compliant and evidence-based (Barrett, 2020, pp. 148-189). The test is general so as to be universally applicable, but its key feature is that it leans towards a rights-based analysis of the quality and content of the laws, policies, and practices States Parties have put in place.

There is an ever-increasing volume of literature around interventions for children and young people in the context of drug use. However, what might be considered human rights compliant measures has been less clear. The UN system, via the Chief Executives Board for Coordination, has also issued a 'common position' on drug policies, which places considerable weight upon the human rights aspects of national responses (UN System Chief Executives Board for Coordination, 2019). Providing even more detail, the International Centre on Human Rights and Drug Policy has developed the International Guidelines on Human Rights and Drug Policy, endorsed by the UN Development Program, the WHO, UNAIDS, and the Office of the High Commissioner for Human Rights. ${ }^{4}$ These includes a dedicated section on children, producing specific guidelines rooted in the work of the Committee on the Rights of the Child and other human rights mechanisms, as well as international standards on drug prevention and other issues.

\section{References}

Barrett, D. (2017). The Child's right to protection from drugs: Understanding history to move forward. Health and Human Rights Journal, 19(1), 263-268.

Barrett, D. (2019). Canada, cannabis and the relationship between UN child rights and drug control treaties. International Journal of Drug Policy, 71, 29-35. https://doi.org/10.1016/j.drugpo. 2019.02.010

Barrett, D. (2020). Child rights and drug control in international law. Brill Nijhoff. Accessed November 15, 2020, from https://brill.com/view/title/55876

Barrett, D., \& Lohman, D. (2020). Incorporating child rights into scheduling decisions at the UN commission on narcotic drugs. International Development Policy I Revue internationale de politique de développement, (12). doi:https://doi.org/10.4000/poldev.3972

Barrett, D., \& Tobin, J. (2019). Article 33: Protection from narcotic drugs and psychotropic substances. In J. Tobin (Ed.), The UN convention on the rights of the child: A commentary (pp. 1273-1309). Oxford University Press.

\footnotetext{
${ }^{4}$ For more information, refer to the interactive website International Guidelines on Human Rights and Drug Policy, https://www.humanrights-drugpolicy.org/
} 
Office of the United Nations High Commissioner for Human Rights \& Rädda barnen (Society: Sweden). (2007). Legislative history of the convention on the rights of the child. United Nations. https://digitallibrary.un.org/record/602462? $\mathrm{ln}=\mathrm{en}$

UN Committee on the Rights of the Child. (2003). General comment no. 3 (2003) HIV/AIDS and the rights of the child, March 17, 2003, CRC/GC/2003/3. Accessed October 12, 2020, from https://digitallibrary.un.org/record/501529? $\mathrm{ln}=$ en

UN Committee on the Rights of the Child. (2010). Treaty-specific guidelines regarding the form and content of periodic reports to be submitted by States parties under article 44, paragraph 1 (b), of the Convention on the Rights of the Child, November 23, 2010, CRC/C/58/Rev.2. Accessed October 12, 2020, from https://digitallibrary.un.org/record/709813? $1 \mathrm{n}=\mathrm{en}$

UN Committee on the Rights of the Child. (2013). General comment no. 15 (2013) on the right of the child to the enjoyment of the highest attainable standard of health (art. 24), April 17, 2013, $C R C / C / G C / 15$. UN. Accessed October 26, 2020, from http://digitallibrary.un.org/record/ 778524.

UN Committee on the Rights of the Child. (2016). General comment no. 20 (2016) on the implementation of the rights of the child during adolescence, December 6, 2016, CRC/C/GC/ 20. Accessed October 12, 2020, from https://digitallibrary.un.org/record/855544? ln=en

UN System Chief Executives Board for Coordination. (2019). Summary of deliberations: Chief Executives Board for Coordination, 2nd regular session of 2018, New York, 7 and 8 November 2018, CEB/2018/2. Accessed November 15, 2020, from http://digitallibrary.un.org/record/ 3792232

Open Access This chapter is licensed under the terms of the Creative Commons Attribution 4.0 International License (http://creativecommons.org/licenses/by/4.0/), which permits use, sharing, adaptation, distribution and reproduction in any medium or format, as long as you give appropriate credit to the original author(s) and the source, provide a link to the Creative Commons license and indicate if changes were made.

The images or other third party material in this chapter are included in the chapter's Creative Commons license, unless indicated otherwise in a credit line to the material. If material is not included in the chapter's Creative Commons license and your intended use is not permitted by statutory regulation or exceeds the permitted use, you will need to obtain permission directly from the copyright holder.

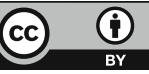

